technical enquiry by people intimately engaged on the work concerned. There should also, however, be room for consideration of the effect on scientific work as a whole since the resources involved may well affect the amount available for work in other fields. Only as we perfect the means for making this process effective and efficient can we hope to avoid falsification of promises that appear to be implied in the application of science, and the consequent frustration and misunderstandings both in the scientific community and in society as a whole. Mr. Maddox's article could scarcely have been better timed to drive home the essential point for Britain in the report on F'ederal Support of Basic Research in Institutions of Higher Learning, at least so far as present discussions on the organization of her scientific effort are concerned; and the recommendations of the report are designed to draw a growing proportion of the scientific community into public discussion. A robust connexion between the making of choices between scientific alternatives and the vitality of the scientific community as a whole is an essential factor in the establishment of sound scientific policy and national economic development to-day. To create and maintain that connexion is at least as much the responsibility of the scientific community itself as of the Government. If, at the present time, political expediency or party prejudices are allowed to hinder the establishment of a sound organization for civil science the responsibility will rest as much on the scientific community as on the politician.

\section{A CLASSIC ON MALAYSIA AND INDONESIA}

The Malay Archipelago

The Land of the Orang-Utan and the Bird of Paradisea Narrative of Travel with Studies of Man and Nature. By Alfred Russel Wallace. Pp. xvii +515. (New York: Dover Publications, Inc.; London: Constable and Co., Ltd., 1962. Originally published 1869.) 2 dollars; $16 s$.

Go many works on and by the 'Castor of Evolution', $\checkmark$ Darwin, have recently been printed or reprinted, that it is a pleasure to welcome the re-publication of a book by 'Pollux', Alfred Russel Wallace, and it is one of his best, The Malay Archipelago. Its importance has always been great, as the first analysis in detail of the geographical distribution of animals and plants examined in the light of evolution and of the geological history and structure of the islands that compose that Archipelago.

The sub-title of the book is The Land of the Orang-Utan and the Bird of Paradise, and it was, in part, the latter that led him to realize the existence and importance of a line that separates Lombok from Bali, and Celebes from Borneo, east of which are found paradise birds, cockatoos, honeysuckers and brush-turkeys, and the prehensiletailed Cuscus, while on the west are found barbets, fruitthrushes, woodpeckers, monkeys and, of course, the orang. Modern treatises on zoogeography, such as that by $\mathbf{P}$. J. Darlington, point out that other important lines can be drawn on the map of the Malay Archipelago (for example, Weber's line of faunal balance between Celebes and the Moluceas), but they do not detract from the importance or value of Wallace's line as a boundary between the Oriental and the Australian faunas. Darwin himself was fascinated by it and, in the Origin of Species, he referred in glowing terms to "Mr. Wallace's admirable researches, in regard to the Great Malay Archipelago", and to the significance of troughs of very deep sea, even when very narrow, separating islands. The establishment of definite boundary-lines between faunas is difficult, especially where the ranges cover a multitude of islands, and the modern tendency is to recognize an intermediate region, east of the Oriental region (marked more or less by Wallace's line) and west of the Australian region (west of New Guinea), and to this intermediate region has been given the name of Wallacea.

Another reason why Wallace's book is welcome has been pointed out by Mr. Tom Harrisson, curator of the Sarawak Museum, in his penetrating study on Wallace and Borneo. "Reading on the spot his [Wallace's] excellent chapters on 'The Malay Archipelago' it is strange to find how many things have not changed in a century". At the present time, when interest in Borneo is awakened, regrettably for reasons that are the reverse of scientific, when there is so much of scientific interest (for example, the Great Cave at Niah) worthy of attention, it is remarkable that the first general work on that fascinating and wide region should still retain such great value. There are, as R. W. C. Shelford remarked in his A Naturalist in Borneo (1916), some points on which Wallace's work stands in need of correction, but nevertheless, it says much for the patience, endurance under difficult conditions, hardihood, and powers of observation of "a single, radical, rather quiet and ultimately cranky man who died at a great old age, and has not succeeded in leaving any vocative progeny even in the form of spirit media or messengers in the afterworld--with which he was in such close connection during his later life" (Harrisson).

It is impossible to refer here to all the countless points of interest raised by Wallace in his great book, but attention may be directed to two. One of those is his observation that of all the checks to increase in population among uncivilized nations mentioned by Malthus, starvation, disease, war, infanticide, vice and infertility, Wallace could find none that had been operative when he investigated the populations of the Sarawak Dyaks which appeared to be stationary in numbers. Here is a subject for new research.

The second is the orang. Wallace, unfortunately, was trigger-happy, and the only distasteful part of his book is that where he describes how he shot one orang after another. To quote Harrisson once more, "Practically all natural history was not done by observation but by assassination". But Wallace did observe, and his observations on these apes are among the very few that have been made in the wild.

Gavin DE BeER

\section{ELECTRONS AT WORK}

\section{Advances in Electronics and Electron Physics}

Vol. 17. Edited by L. Marton, with the assistance of Claire Marton. Pp. $x+451$. (New York: Academic Press, Inc.; London: Academic Press, Inc. (London) Ltd., 1962.) $100 s$.

7 HIS series of review articles, several to a volume, is now well established; the editorial board continues to exercise a broad interpretation of the main title, for two of the five articles in this volume are on "Thermoelectricity" and "Ultra-high Vacuum".

However, inclusion of the first and longest article is appropriate by any interpretation. It derives the smallsignal equations expressing tho interaction between a beam of electrons and the electromagnetic field of an adjacent space harmonic circuit. The analysis is detailed, with the mutual effects expressed in terms of field theory rather than equivalent circuit concepts; only experts can judge the practical value to the design of travelling wave tubes.

By contrast, the second article, on thermionic energy conversion, is almost wholly descriptive. The subject attracts attention because it promises direct conversion 